\title{
LANDSCAPE INTERVENTION DESIGN STRATEGY WITH APPLICATION OF ISLAMIC ORNAMENTATION AT TRUNOJOYO PARK MALANG, JAWA TIMUR, INDONESIA
}

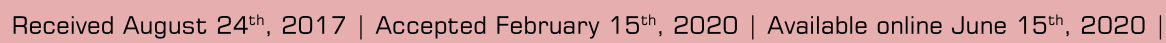

DOI http://dx. doi.org/10.18860/iia.v6i1.4383 |

Harida Samudro

Department of Architecture Engineering Faculty of

Science and Technology,

Universitas Islam Negeri Maulana Malik Ibrahim

Malang. Indonesia.

Email:haridasamudro@gmail.com

\begin{abstract}
Trunojoyo Park in Malang City is one of the city parks that has a predicate as the best park. The government of Malang city supports this park into a city park that must be visited by the tourists. The problem is trunojoyo park requires a direction of future development by looking at the perception of visitors who visit the park. The purpose of this study is to know the direction of the new design to find the appropriate design criteria in relation to one's response from the perceptions seen. The architectural intervention in the landscape is one way of approaching how to view the perception in the realm of architectural design. In two ways: temporary intervention and permanent intervention, this method looks at how one's response perceives the architectural element as an aesthetic element in which there is an Islamic ornament as one of the objects applied. This study used descriptive research through field observations by giving random questionnaires that were divided into men and women. Analysis and discussion are done by sorting and calculating each variable of choice of the respondent (quantitative). They were further evaluated to determine the factors of visitor perception assessment of aesthetics Park City. This study shows that the order and diversity of vegetation, completeness of facilities, security, and comfort of the Park City are the factors of assessment of visitors to the aesthetics of the Park City. This research has benefited from the emergence of new theories regarding the visitor's assessment of the aesthetic City Park.
\end{abstract}

\section{KEYWORDS:}

City Park; Malang Trunojoyo Park; Architectural design strategy; Landscape Intervention; Islamic Ornaments

\section{INTRODUCTION}

The development of the city of Malang has a lot out of the original plan. Malang city is experiencing the same symptom that changes in the function of land, which is planned as a green open space or city park become built area [1]. Public space is a space that can be accessed by the community in a limited time or not sure. Green open space can be shaped by roads, sidewalks, city parks, and urban forest [2]. The city of Malang is famous for its fresh air and its clean and beautiful city. To support the activities of Malang city residents and visitors of Malang city in the open air, then built several parks scattered in various parts of the city [3]. These gardens have a unique concept; one of them is merbabu park, trunojoyo park, merjosari park, and the biggest is the town square unfortunate.

The park located in the city of Malang is a green open space with a minimum area of $30 \%$, this percentage is a minimum size of vegetation area to ensure the balance of the ecosystem of the region [4]. The balance of ecosystems maintained is a hydrological function, microclimate, the availability of clean air to be guaranteed for the needs of its citizens, and the absorption of carbon dioxide. Also, the vegetated area can increase the aesthetic value of the city [5]. The decreasing quality of urban settlements can be seen from the increasingly severe congestion, the development of slums susceptible to flooding, and the increasing loss of green open space for articulation and public health. Urban parks can be categorized as spaces where plants grow and are useful, and plant types grown in city parks are tree plants, shrubs, bushes, vines, and herbaceous plants [6]. Park City has the power to shape the character of the city and maintain the quality of its environment [7]. The city landscape is human-made as a result of human activities in managing the environment to meet the needs of life [8].

Green space landscape is an innovation of the concept of a city park on how to make a city park has a function as the lungs of the city and as a comfortable place through the provision of supporting facilities to maintain environmental sustainability [9]. Roadside areas are areas that work for the safety and convenience of road users, land for road development, buffer zones, green lines, service facility development 
sites, and protection of natural formations [10].

The limitation of green space demands a separate regional regulation that regulates policies such as the replacement of massive multi-story building blocks with trees and shade-functioning parks that can blend into the sidewalks at the edge of the roads [11]. Landscape management is an integrated effort in the arrangement and utilization, maintenance, preservation, control, and development of the environment to create a landscape that is beneficial to humans and other living things [12]. Management is a process of conceptualization, theory, and objective analysis, which is to plan, organize, and run the goal through the systematic, coordinative, and cooperative efforts of the man [13].

Landscape intervention aims to analyze and determine the factors that become assessments of adolescent perceptions of the aesthetics of Park City. The method of intervention is done by descriptive, direct observation in the field, involving elements of intervention divided into two stages: interim intervention and permanent intervention [14]. Interim intervention is determined by time weather; the goal is to encourage people to engage with water, wind, and plants. Permanent interventions are determined based on existing objects in the garden by placing pots of plants, materials, and Islamic ornaments in favor of landscape design [15]. The data were collected by random sampling. Analysis and discussion are done with the use of supporting elements, so researchers are trying to encourage more development towards social, emotional, and cognitive. The benefit of this research is to know the factors of visitor perception assessment to trunojoyo park aesthetics, that during this park trunojoyo as one of the city parks in Malang more functioning as a place of social interaction.

\section{METHODS}

The Trunojoyo area was chosen as a study site based on the consideration that the domain is part of a historical city center and has diverse functions from government, residential, commercial, and public facilities. Strategic location and the gathering of critical public facilities such as railway stations, schools, and some government offices make the area have high vitality potential. However, the region development indicates the opposite condition in which the vigorous healthiness continues to decline both physically, socially, and economically.

The open park is strategically located in the center of town, right in front of New Town Station. Side by side with Tugu Square and Malang City Hall. Inaugurated on June 1st, 2014, by the Mayor of Malang, Moch Anton, this city park is named Bentoel Trunojoyo Park or Trunojoyo Intelligent Garden. Potentials that exist in this park is a predominant green garden area of grass that began to order. Under the giant trembesi tree beside the gazebo, some of the flowers are much more orderly pretty neat. Among them are garden lights and sprinkler's automatic watering faucet. When observed in more detail, there are water absorption sites (Biopori) made at many points of the park, absorption wells, and also bins. This is a 'green' effort done by Malang City Government to be friendly to the environment, Figure 1.

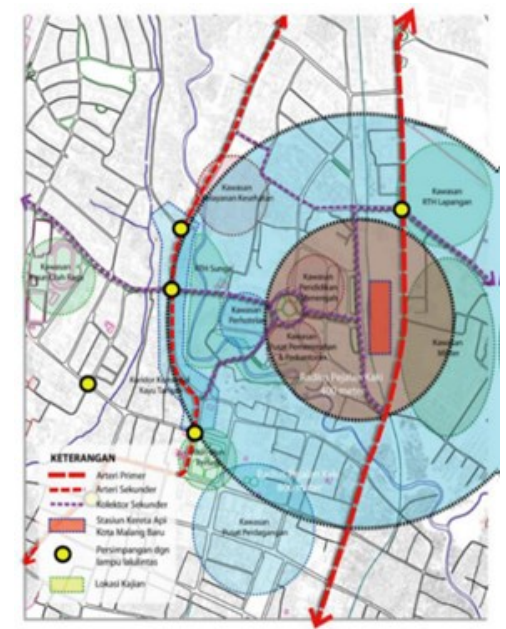

Figure 1. Location of trunojoyo park to the surrounding environment.

Trunojoyo Park is divided into two parts, namely the north and south. In the northern part of the facilities provided are fountain spaces for children, playground swings, etc., sand playground for children, a library for reading, healthy stone arena or health stone, toilets, garbage cans, Children, seating arranged for leisure or chatting, parking, and wifi are also provided figure 2 . Then on the south side, there is also a gazebo or lounge to relax and chat, food court area, art installation, theater area Open, and parking lot.

Figure 2 shows the northern trunojoyo park layout. Trunojoyo Park includes a good park indicator because it is designed with an attractive, lush atmosphere, a strategic place that is easy to pass by the city transport vehicle, close to shops, figures 3 and 4 .

Regarding the community's preference for green space in the park, there is an understanding of people's perceptions and attitudes toward the condition of the surrounding environment. Knowledge is defined as organizing and translating the stimulus that results in behavior and attitudes. Action is a process of interaction between personality and atmosphere that contains stimulus (stimulus), then responded in the form of response. This response is called behavior. Behavior is determined by perception and personality, while the experience motivates attitudes and personality.

Perception has a vital role in decision making. Knowledge is defined as a psychological function that allows the individual to observe sensory stimuli and turn them into an organized journey. The human response to the environment depends on how the individual perceives his environment. The perception of the environment affects individual relationships with their environment. 


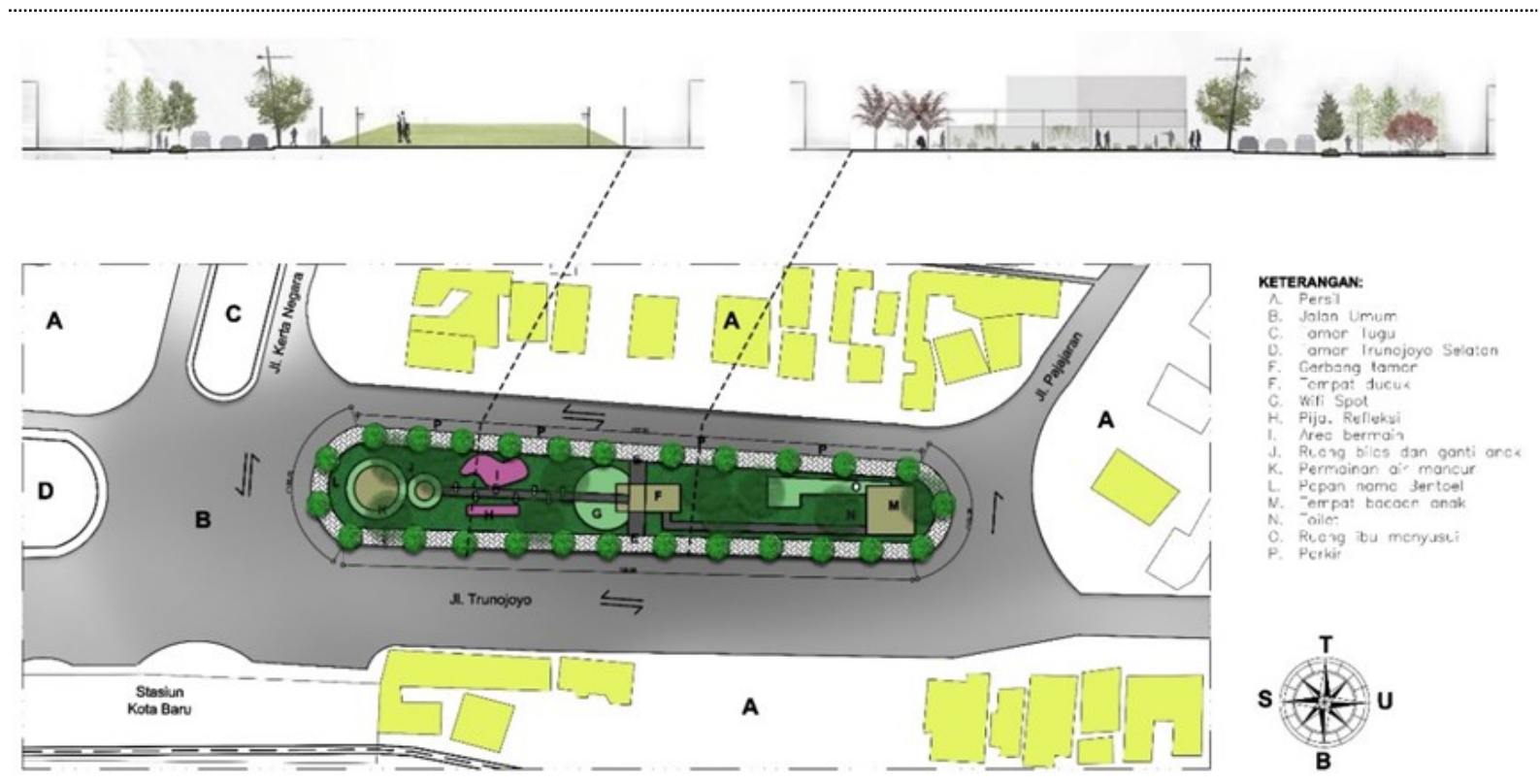

Figure 2. The northern trunojoyo park layout

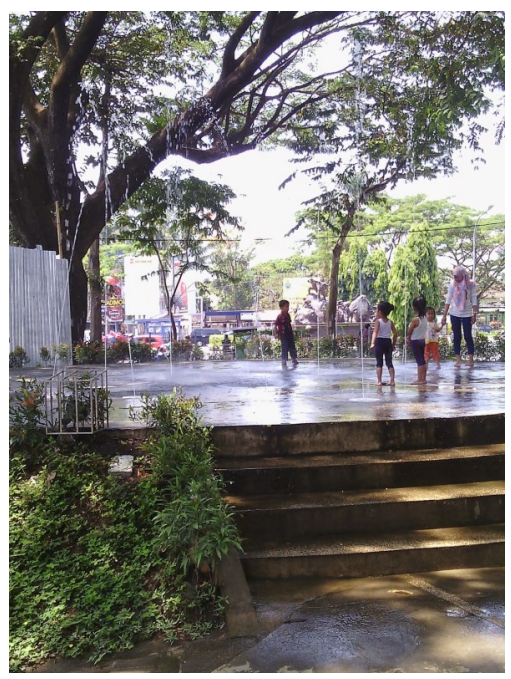

Figure 3. Water fountain for all ages

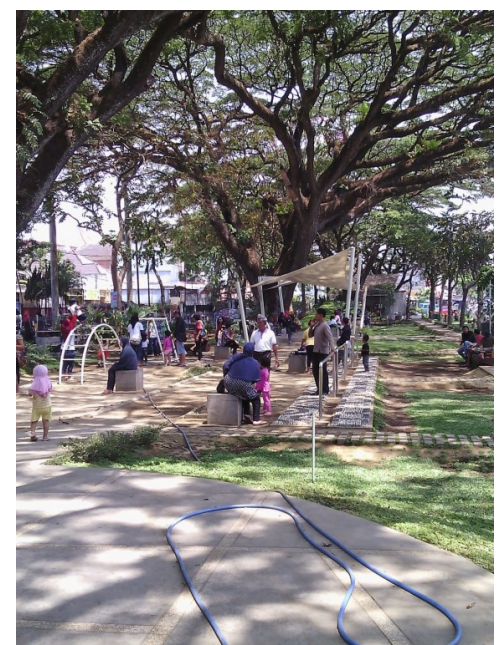

Figure 4. Footstone area for health therapy
This research is included in the analytical descriptive study, which aims to explain deductively in the form of a picture of the existing problems on the quality of Malang city park from the aspect of public preference. The community preference parameters will focus on practical methods, an approach by defining design criteria that will be achieved using existing data to get the expected design direction.

The process are a) Determining the variables of any factors that become the assessment of visitors' perception of the Park City aesthetics part, by capturing 100 respondents (table 1), and b) Spread the questionnaire by listing the variables that have been found previously to perform the sound calculation by Level of education, age, and sex level, to determine which variables are the most up to the third order, by the assessment of the adolescent's perception [16]. Conduct the architectural intervention of temporary intervention in the form of time/weather, and permanent intervention in the form of potted plants, Islamic ornament, figure 5 [15].

Tabel 1. Voting of visitors to the city park.

\begin{tabular}{llc}
\hline No & $\begin{array}{l}\text { Variable perception of visitors to the } \\
\text { city park }\end{array}$ & $\begin{array}{c}\text { Respondent } \\
\text { Numbers }\end{array}$ \\
\hline 1 & Facility completeness of City park & 22 \\
2 & $\begin{array}{l}\text { Safety and comfort of visitors in City } \\
\text { park }\end{array}$ & 18 \\
3 & Arrangement \& diversity of vegetation & 25 \\
& in City park & 12 \\
5 & Social interaction in City park & 15 \\
6 & Cleanliness/health of City park & 8 \\
\hline & No idea & $\mathbf{1 0 0}$ \\
\hline
\end{tabular}


Table 1 illustrates the most significant visitor response is at number 3 , relating to the arrangement and diversity of plants in urban parks. It can be concluded that the presence of plants to make architectural intervention can be created by presenting a comfortable and pleasant atmosphere.

Ornaments are components of art products that are added or deliberately made for decoration. As an implicit decorator concerning aspects of beauty, people often find symbolic values in the ornaments that have something to do with the view of life (philosophy Life) of the human or the society of the maker, so that the objects it produces have profound meaning and meaning, along with certain expectations as well [17].

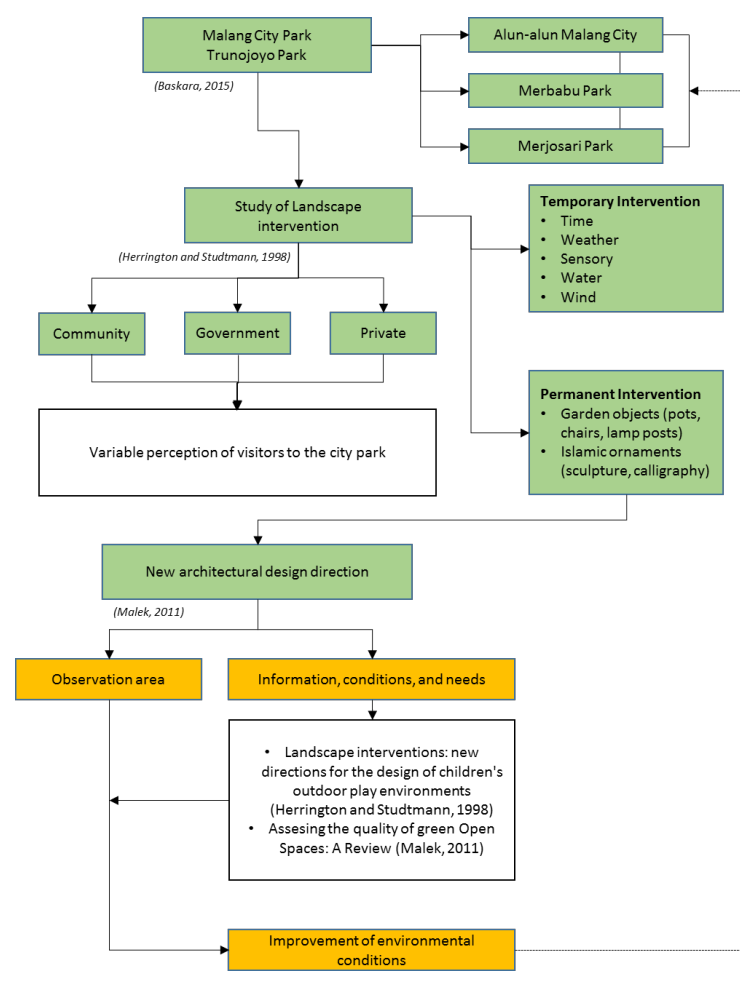

Figure 5. Flowchart relation of visitor perception variable to architectural intervention.

The application of Islamic ornaments about architectural intervention is how people's perception realizes that the concept of Allah's majesty can be seen as a strengthening of the faith. These ornaments will be arranged and placed based on their function and function.

The early Islamic tile artists were inspired by the works of Euclid, Pythagoras, and other mathematicians of antiquity. Islam forbids the use of humans and animals in religious artwork, so they used geometric shapes instead. Islamic tile designs come in many shapes and forms. They can also be created in different ways. One standard method is Zillij, the art of using glazed tiles to form geometric patterns [18].

Artists using this style lay shapes from clay ad put them facing the surface on which they are working on into the lines of their design. Once they finish tiling, the artists pour concrete over the tiles to form a slab. They lift the entire mosaic when the concrete hardens. Then they attach the beautiful art to a building or other structure. There are many different Islamic designs ornaments such as calligraphy, geometric (pentomino squares, rectangles, triangles, 8-pointed star, hexagons, 3-D effect), and arabesque [19], figure 6.
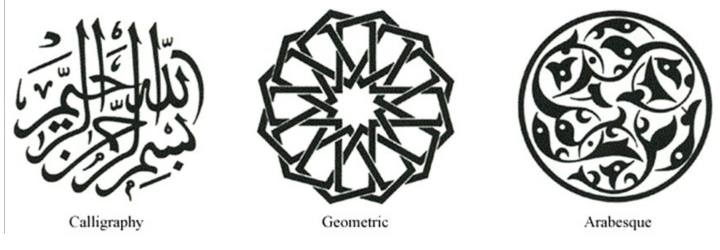

Figure 6. Types of Islamic ornaments

\section{DISCUSSION}

City Park for the public, in general, is widely used as aesthetic fulfillment, fresh air fulfillment, recreation, relaxation, a place to get rid of saturation, a place to chat with family or friends, and various other activities [20].

The city government of Malang has built dozens of Park City Active. The people, desperately needing City Park as an alternative to the fulfillment of aesthetics, recreation, and relaxation, it is characterized that the City Park is crowded once visited by the visitors.

The study took a case study of Trunojoyo Park because Park City has complete facilities as a City Park, has aesthetic values, recreation, and relaxation. This park, an active City Park that has been known by many people, as citizens of Malang city of East Java Province Indonesia. The park is visited by thousands of visitors every holiday that is dominated by tourists.

Trunojoyo Park is a concept park as a place of recreation, relaxation and leisure activities and sports for children, and the general public. Besides, trunojoyo park also serves as a container of religious activities for the community [21].

By providing temporary and permanent architectural intervention of Islamic park concept based on Islamic Shari'a, taking into account the relationship to the Creator of Allah Subhanahuwata'ala and relationship to fellow human beings and care for the environment. Trunojoyo Park is not only as a place of recreation but also a place to pay attention to God's creation and contemplate it.

The basis of this architectural intervention is to emphasize the Islamic ornament approach that will be placed in several places within the park. The public perception variable will show how this architectural intervention provides a new design direction.

This study was conducted by collecting the results of the visitors' response by spreading questionnaires to the respondents; it is done to determine what factors into the assessment of visitor perceptions of the aesthetics of the Park City. The process is to distribute questionnaires to 150 (one hundred and fifty) respondents according to gender with the division of each 75 (seventy-five) surveys of each sex, by using the 
perception of visitor's ax- tics to aesthetic appraisal variable, table 2.

\begin{tabular}{llccc}
\multicolumn{5}{c}{ Table 2. Voting of visitors to urban parks by gender. } \\
\hline \multirow{2}{*}{ No } & $\begin{array}{l}\text { Variable perception of } \\
\text { visitors to the city park }\end{array}$ & Male & Female & total \\
\cline { 2 - 5 } 1 & $\begin{array}{l}\text { Facility completeness of } \\
\text { City park }\end{array}$ & 15 & 16 & 31 \\
2 & $\begin{array}{l}\text { Safety and comfort of } \\
\text { visitors in City park }\end{array}$ & 14 & 17 & 31 \\
3 & $\begin{array}{l}\text { Arrangement \& diversity } \\
\text { of vegetation in City park }\end{array}$ & 18 & 17 & 35 \\
$4 \quad \begin{array}{l}\text { Social interaction in City } \\
\text { park }\end{array}$ & 13 & 12 & 25 \\
5 & $\begin{array}{l}\text { Cleanliness/health of City } \\
\text { park }\end{array}$ & 15 & 13 & 28 \\
\hline & $\quad$ TOTAL & 75 & 75 & 150 \\
\hline
\end{tabular}

Table 2 shows that the selection of the five variables performed by men and women, almost balanced, and the number is not conspicuous, even variable names one and number two, the same amount of 31 respondents respectively. The highest number remained at variable number three, i.e., the order/ diversity of vegetation in Park City, with 35 respondents, with the details of 18 selected by male and 17 male respondents selected by female teenage respondents. While the number four variable, the Social Interaction at Taman Kota, is at the smallest number, only chosen by 25 respondents with details selected by 13 male respondents and 12 by teenage respondents. Direct observation in Trunojoyo Park proves that respondents of both men and women choose variables of vegetation arrangement at Park City (number 3) as supporting factors of perception assessment of aesthetics of City Park. Based on table 1 and table 2, it can be explained that the variables of structuring and diversity significantly affect the visitor's perception of trunojoyo park. This perception reinforces that architectural intervention can be done by providing temporary intervention and permanent intervention in re- sponse to the variable. A brief intervention can be seen in table 4.

Table 4. Interim interventions on the variables of urban park management and diversity

\begin{tabular}{cccc}
\hline \multirow{2}{*}{ No } & $\begin{array}{c}\text { Permanent } \\
\text { Intervention }\end{array}$ & \multicolumn{2}{c}{ Design strategy } \\
\cline { 3 - 4 } & Garden objects & Arrangement & Arrangement \\
\hline 1 & (pots, chairs, & The & Shade plants, \\
lamp posts, etc.) & area uses \\
paving, \\
pedestrian \\
area on the \\
\end{tabular}

Table 5. Permanent intervention on the variables of urban park management and diversity

\begin{tabular}{|c|c|c|c|}
\hline \multirow{2}{*}{ No } & \multirow{2}{*}{$\begin{array}{l}\text { Temporary } \\
\text { Intervention }\end{array}$} & \multicolumn{2}{|c|}{ Design strategy } \\
\hline & & Arrangement & Diversity \\
\hline 1 & Time & $\begin{array}{c}\text { Setting hours } \\
\text { of visit }\end{array}$ & $\begin{array}{c}\text { Giving } \\
\text { variation in } \\
\text { park }\end{array}$ \\
\hline 2 & Wheather & $\begin{array}{l}\text { Adjustment } \\
\text { to Local } \\
\text { Climate }\end{array}$ & $\begin{array}{c}\text { Have } \\
\text { diverse } \\
\text { shadowing }\end{array}$ \\
\hline 3 & Sensory & $\begin{array}{c}\text { Placing } \\
\text { objects of } \\
\text { architecture } \\
\text { according to } \\
\text { the senses of } \\
\text { visitors }\end{array}$ & $\begin{array}{l}\text { Increase } \\
\text { the } \\
\text { pleasure } \\
\text { factor in } \\
\text { the park }\end{array}$ \\
\hline
\end{tabular}

Table 4 explains that temporary intervention can provide new directions of designs in trunojoyo parks tailored to the variables of arrangement and diversity

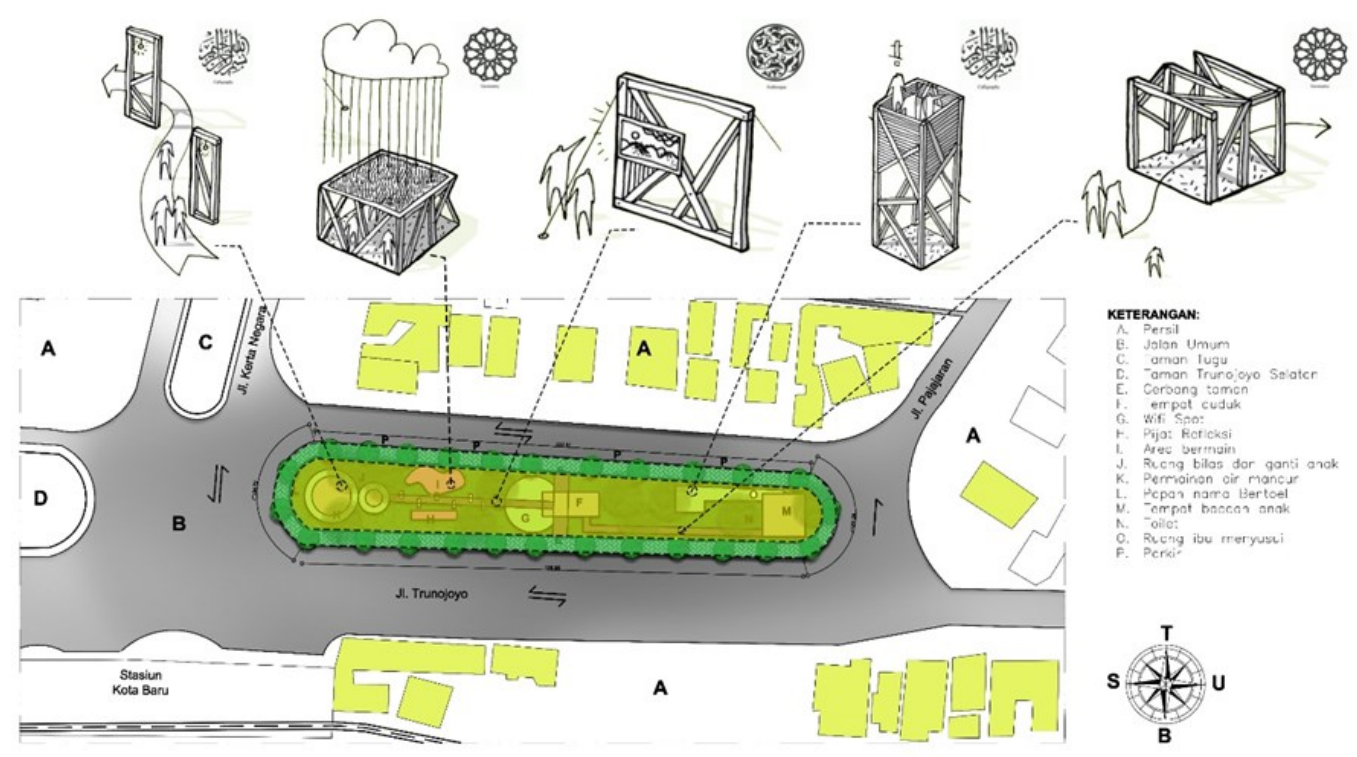

Figure 6. placement of architectural landscape intervention 
within urban parks. The new directive of this design indicates that the architectural intervention provides unique insight into the city park, especially the trunojoyo park, to become a more beautiful and comfortable park.

Furthermore, the permanent intervention focused on garden objects to be studied based on the highest variables of the city park is shown in table 5 .

Table 5 explains that the permanent intervention provides Islamic design guidance where there is a value of mercy for nature (rahmatan Lil Alamin). In designing, it is necessary to pay attention to the influence of life after it or the impact on the environment. In addition to humanizing humans, human beings are designers; then, the main priority is social as a user. An arrangement of greening layout becomes dominant in the tread as a manifestation of guarding Allah's creation and reminding humans to need nature.

By leveraging the architectural elements as a way to intervene in the trunojoyo park, the future development of the trunojoyo park will have a distinctive feature as a beautiful and comfortable park used by visitors both from domestic and abroad. This intervention can also be used for other city parks to create park integration within a city.

Figure 6 explains that Temporary intervention is the green color is placed on the outer part of the park because of time, weather, and sensory considerations more put forward elements of taste. In contrast, the permanent intervention is the yellow color placed on the inside of the park because of the review of garden objects, and Islamic ornaments that put forward the activity of space in the park.

\section{CONCLUSION}

Based on the results of the study and field observations on the respondents, it can be concluded that the assessment of visitor perceptions of the aesthetics of Park City, the order, and the diversity of existing vegetation, especially vegetation that serves as ornamental vegetation and vegetation conditioning. Completeness of facilities owned by Park City is also a factor that became the assessment of the aesthetic perception of Park City. The security and comfort felt by visitors of Taman Kota, also become one of the perception valuation factors to the aesthetics of City Park.

This phenomenon has shifted the common perception that the most dominant City Park is considered to be a place of social interaction. It turns out that the City Park is the place to get the aesthetic of the arrangement and the diversity of vegetation, the various facilities, the security and tranquility for the visitors of the Park, Youth. Park City, filled with a variety of plants, also has a function to support the quality of urban open spaces, such as aesthetic qualities, so that teenagers can capture and give a positive attitude as a form of perception in the Park City.
Also, this study creates a forum for activities related to recreation, education, and sports, creating designs of Islamic conceptual parks and also determining the space needed by a park area and the laying of vegetation by the Islamic concept with the application of Islamic ornaments.

\section{REFERENCES}

[1] N. Sesanti, E. B. Kurniawan, and M. Anggraeni, "Optimasi Hutan Sebagai Penghasil Oksigen Kota Malang," Jurnal Tata Kota dan Daerah, vol. 3, no. 1, pp. 65-74, 2011.

[2] R. Andriani, I. A. Rohiim, A. Z. Jannah, F. R. Balqis, and H. Samudro, "Integrating Islamic Aspect for Achieving Local Wisdom Principles Design in Roof Shape of Mosque, Case Study: Demak Mosque," in Proceedings of the International Conference on Green Technology, 2019, pp. 79-83.

[3] A. Y. Putri, "Pola Pemanfaatan Ruang pada Taman Trunojoyo Kota Malang," Universitas Brawijaya, 2017.

[4] N. Herlina, W. S. D. Yamika, and S. Y. Andari, "Karakteristik Konsentrasi Co2 dan Suhu Udara Ambien Dua Taman Kota di Malang," Journal of Natural Resources and Environmental Management, vol. 7, no. 3, pp. 267-274, 2017.

[5] A. Baharudin, "Kebutuhan Ruang Terbuka Hijau Pada Kawasan Pusat Kota Jayapura," Jurnal Bumi Lestari, vol. 11, no. 2, pp. 297-305, 2011.

[6] A. Y. Putri, J. Ernawati, and S. Ramdlani, "Pola Aktivitas pada Ruang Publik Taman Trunojoyo Malang," Jurnal Mahasiswa Jurusan Arsitektur, vol. 5, no. 4, 2017.

[7] N. Imansari and P. Khadiyanta, "Penyediaan hutan kota dan taman kota sebagai ruang terbuka hijau (RTH) publik menurut preferensi masyarakat di kawasan pusat Kota Tangerang," Jurnal Ruang, vol. 1, no. 2, pp. 101-110, 2015.

[8] J. O. Simonds and B. W. Starke, Landscape Architecture. New York: McGraw-Hill Book Co., 2006.

[9] C. Kusmana, "Keanekaragaman hayati (biodiversitas) sebagai elemen kunci ekosistem kota hijau," Jurnal Pros Sem Nas Masy Biodiv Indon, vol. 1, no. 8, p. 1749, 2015.

[10] P. L. Carpenter, W. T.D., and F. O. Lanphear, Plant in The Landscape. San Fransisco: W.H. Freemann And Company, 1975.

[11] D. J. P. Ruang, Ruang Terbuka Hijau Sebagai Unsur Utama Tata Ruang Kota. Direktorat Jenderal Penataan Ruang, 2006.

[12] H. S. Arifin and N. H. . Arifin, Pemeliharaan Taman, Cetakan VI. Jakarta: Penebar Swadaya, 2005. 
[13] R. G. Kraus and J. E. Curtis, Creative Management in Recreation and Park. London: The C.V. Mosby Company, 1982.

[14] S. Herrington and K. Studtmann, "Landscape interventions: new directions for the design of children's outdoor play environments," Landscape and Urban Planning, vol. 46, no. 2-4, pp. 191-205, 1998.

[15] N. A. Malek, M. Mariapan, M. K. M. Shariff, and A. Aziz, "Assessing the quality of Neighbourhood Parks," Australian Journal of Basic and Applied Sciences, vol. 5, no. 10, pp. 743-753, 2011.

[16] Suharto, Dasar-dasar Pertamanan: Menciptakan Kerindangan dan Kerindangan. Jakarta: PT. Media Wiyata, 1994.
[17] S. Cenani and G. Cagdas, "Shape grammar of geometric Islamic ornaments," in Proceedings of the 24th eCAADe, pp. 290-297.

[18] A. S. Jan and S. A. Shaker, Symmetries Of Islamic Geometrical Patterns. World Scientific, 1995.

[19] Y. Abdullahi and M. R. B. Embi, "Evolution of Islamic geometric patterns," Frontiers of Architectural Research, vol. 2, no. 2, pp. 243-251, 2013.

[20] C. Buhari, Profil. Surabaya: Dinas Kebersihan dan Pertamana Kota, 2013.

[21] N. Aini, R. D. Supriharjo, and H. Sulistyarso, "Optimizing The Ecological Functions Of Public Green Space In Klojen Sub-District, Malang City," Journal of architecture\&ENVIRONMENT, vol. 14, no. 2, pp. 109-122, 2015. 